\title{
EVALUATION OF SOME CHELATING AGENTS EFFICACY IN TREATMENT OF LEAD TOXICITY: HAEMATOLOGICAL, BIOCHEMICAL AND HISTOPATHOLOGICAL STUDIES
}

\author{
DIEFY A. SALEM ${ }^{*}$; AHMED A. SHARKAWY*; MANAL M. SAYED ${ }^{* *}$ and SHEHATA, O.A.** \\ ${ }^{*}$ Forensic Med. and Toxicology Dept., Fac. of Vet. Medicine, Assiut University. \\ *** Animal Health Research Institute, Assiut. \\ Email: diefy_salem@yahoo.com
}

\section{ABSTRACT}

Received at: 5/8/2014

Accepted: 3/9/2014
The aim of the study was to evaluate efficacy of DMSA and DMPS in treatment of lead toxicity in albino rats. One hundred twenty male albino rats were divided into four groups $\left(30\right.$ each). The first was used as control, the $2^{\text {nd }}$ group was exposed to lead acetate in drinking water $(100 \mathrm{ppm})$ for 12 weeks, the $3^{\text {rd }}$ group was exposed to lead acetate as in $2^{\text {nd }}$ group together with DMSA $(135 \mathrm{mg} / \mathrm{kg}$ bworally by intubation) and the $4^{\text {th }}$ group was exposed to lead acetate as in $2^{\text {nd }}$ group together with DMPS (200 mumol $/ \mathrm{kg}$ bw IP). The result revealed that the RBCs count showed a significant decrease in $2^{\text {nd }}$ group while in $3^{\text {rd }}$ and $4^{\text {th }}$ was recorded in the last $10^{\text {th }}$ and $12^{\text {th }}$ weeks. The mean corpuscular volume (MCV) showed a significant decrease at the $6^{\text {th }}-12^{\text {th }}$ week in $2^{\text {nd }}, 3^{\text {rd }}$ and $4^{\text {th }}$ groups haematocrit percent $(\%)$ showed significant decrease in $2^{\text {nd }} \& 4^{\text {th }}$ groups all over the study and in $6^{\text {th }}, 8^{\text {th }}, 10^{\text {th }}$ and $12^{\text {th }}$ weeks in $3^{\text {rd }}$ group. Haemoglobin level showed a significant decrease in $2^{\text {nd }}$ and in $8^{\text {th }}, 10^{\text {th }}$ and $12^{\text {th }}$ weeks in $4^{\text {th }}$ and only at $12^{\text {th }}$ in $3^{\text {rd }}$. A significant decrease in $\mathrm{MCH}$ values was recorded $2^{\text {nd }}, 3^{\text {rd }}$ and $4^{\text {th }}$ groups. WBCs count showed a significant increase in $2^{\text {nd }}, 4^{\text {th }}$ weeks in group $2^{\text {nd }}$ and $3^{\text {rd }}$ while decreased at $10^{\text {th }} \& 12^{\text {th }}$ weeks. In $4^{\text {th }}$ group, a significant decrease was noticed at $6^{\text {th }}, 8^{\text {th }}, 10^{\text {th }}$ and $12^{\text {th }}$ weeks. Serum AST and ALT showed a significant decrease at the $12^{\text {th }}$ week in $2^{\text {nd }}$ and increase at the $2^{\text {nd }}$ week in both $3^{\text {rd }}$ and $4^{\text {th }}$. Gamma-GT showed no significant change in $2^{\text {nd }}$ in comparison with group 1. A significant decrease in $3^{\text {rd }}$ and $4^{\text {th }}$ was recorded at the $2^{\text {nd }}, 4^{\text {th }}$, and $6^{\text {th }}$ weeks in comparison with $1^{\text {st }} \& 2^{\text {nd }}$. The histopathological examination revealed a clear variance between group $2^{\text {nd }}, 3^{\text {rd }}$ and $4^{\text {th }}$. Most of the recorded lesions in the liver, kidney and brain of $2^{\text {nd }} \& 4^{\text {th }}$ groups at severe or moderate degree were absent or in a mild form in group $3^{\text {rd }}$. In conlusion the two chelating agents (DMSA \& DMPS) used run in nearly similar manner as every one has special advantages in treatment.

Kew words: Lead - DMSA - DMPS - RBC count - histopatholohy-enzymes.

\section{INTRODUCTION}

Lead is ubiquitous in the environment, and it is used in a large variety of products. Sources of exposure for animals include lead weights (e.g., fishing sinkers, curtain weights), lead- based paints, lead solders, wire shielding, old metal tubes, automotive batteries, leaded gasolines or oils, pumbing caulks, old leaded pipes, linoleum, leadcontaining toys, computer equipment, roofing felt, window putty, improperly glazed pottery, lead arsenate pesticides, lead shot for guns, wine cork covers, and contamination of pastures near smelters (Sullivan and Kriger, 1992). Livestock may find lead in rubbish dumps and around farm buildings and machinery. Lead shot may be a source of poisoning of domestic poultry and wild birds. It is most often seen in water fowl, such as ducks and geese, which swallow lead shot and fisherman's sinkers from the bottom of lakes and ponds (Siddiqui and Gayatri, 2008).

Lead has multiple effects on biochemical mechanisms within the body, including binding of cellular and enzymatic sulfhydryl groups, competition with calcium ions, inhibition of membrane-associated enzymes, and alteration of vitamin D metabolism. Lead binds sulfhydryl groups, resulting in inactivation of enzymes involved in heme synthesis, such as $\delta$-Aminolevulinic Acid Dehydratase (ALAD) and ferrochelatase, and causing red blood cell abnormalities (Abadin and Llados, 1999). Lead causes anemia when it combines with red blood cells and bone marrow. It damages the 
small blood vessels, causing bleeding، and deprives the nerves, the brain and other organs of oxygen. Lead severely damages the kidney and liver. It also causes sterility, fetal death and abortion. All animals with access to a source of lead are at risk. When one or two animals in a herd die or show signs of poisoning, other animals in the herd may also be suffering from lead poisoning. These animals may appear healthy, but be growing poorly as a result of subclinical lead poisoning (Siddiqui and Gayatri, 2008).

In animals, lead induces heme oxygenase, an enzyme involved in catabolism of heme which could exacerbate deficiency of heme. Inhibition of heme synthesis by lead has implications on many other processes in the body as heme is an integral part of myoglobin, catalase, mitochondrial and microsomal cytochromes, tyrosine hydroxylase, nitric oxide synthase etc., hence heme related functions such as mitochondrial respiration, and microsomal drug metabolism and neurotransmitter synthesis may also get compromised due to lead toxicity (Anjana, 2009).

Chelation is a chemical process in which specific chemical antidote reacts with metal protein complex, combined with the metal and leaves the protein free. Most of chelators contain two thiol groups; therefore, they attract metal to combine with them. The combined metal chalet's forms stable complex and mostly excreted through urine (Osweiler, 1996).

DMPS (2,3-dimercapto-1-propanesulfonic acid) is a chemical analog of BAL, has greater water solubility than BAL, limited lipid solubility and is effective when given orally. In addition, this chelator is less toxic than BAL and consequently can be administered in high doses (Aposhian and Aposhian, 1990, Anderson, 1991). Sodium dimercaptopropane sulfonate (Na-DMPS) was able to chelate heavy metals and metalloids (Chen and Lu, 2004).

DMSA (dimercapto succinic acid) has been licensed as a drug by the U.S. Food and Drug Administration (FAD) specially for treatment of lead poisoning in children whose blood levels are $>45 \mathrm{~g} / \mathrm{dl}$, and it has been used in Europe (O'Connor and Rich, 1999).

The study aims to evaluate the efficacy of DMPS (23-Dimercapto-1-Propane Sulfonic acid) and DMSA (Meso-2,3-Dimercapto Succinic acid) as a chelating agents in case of long-term exposure to lead.

\section{MATERIALS and METHODS}

\author{
Materials:- \\ 1- Chemicals: DMPS (2,3-Dimercapto-1- \\ propanesulfonic acid sodium salt), monohydrate
}

(DMPS) , Purity: 95\% $\mathrm{C}_{3} \mathrm{H}_{7} \mathrm{O}_{3} \mathrm{~S}_{3} \mathrm{Na}$ and DMSA (meso-2,3-Dimercapto succinic acid) of 98\% purity $\mathrm{C}_{4} \mathrm{H}_{6} \mathrm{O}_{4} \mathrm{~S}_{2}$ was obtained from Sigma Chemical Co., Germany. Lead acetate $\left[\mathrm{Pb}\left(\mathrm{CH}_{3} \mathrm{COO}\right)_{2} \cdot 3 \mathrm{H}_{2} \mathrm{O}\right]$ with molecular weight of 379.35 was obtained from B.D.H laboratories chemicals division Poole, England.

2- Animals: One hundred and twenty male albino rats weighting 100-150 g (10-12 weeks old) were used. The rats were acclimatized to laboratory condition two weeks before the experiment. Food and water were available add libitum, suitable temperature and lighting cycle of 12 hours (light/dark) were in consideration.

3- Experimental Design: The rats were divided into four groups $\left(30\right.$ each). The $1^{\text {st }}$ group was used as control, the $2^{\text {nd }}$ group exposed to lead acetate in drinking water (100 ppm) for 12 weeks, the $3^{\text {rd }}$ group exposed to lead acetate as in $2^{\text {nd }}$ group together with DMSA (135 mg/kg bworally by intubation) and $4^{\text {th }}$ group was exposed to lead acetate as in $2^{\text {nd }}$ group together with DMPS (200 mumol/kg bw IP).

4- Sampling: Blood samples (with EDTA as anticoagulant for estimation of hematological parameters and without anticoagulant to obtain serum for estimation of biochemical parameters) and tissue samples (liver, kidney and brain samples for histopathological examination) were taken from five rats from each group at 2, 4, 6, 8, 10 and 12 weeks.

\section{Methods:}

1- Hematological parameters were done using Vet hematology analyzer (Medonic CA620 Vet, Boule Medical AB, Stockholm, Sweden).

2- Biochemical parameters: Serum aspartate aminotransferase (AST) and alanine aminotransferase (ALT) activities were estimated as described by Henery (1960) by using commercial kits (Diamond Diagnostics. Hannover, Germany). Gamma- GT ( $\gamma$-GT) was measured spectrophotometrically according to Tietz, (1994) by using commercial kit (Chema Diagnostica, Italy).

3- Histopathological examination: Specimens were obtained from each animal and fixed in $10 \%$ neutral buffer formaline. Sections of $5 \mu \mathrm{m}$ thicknesses were microtomed and stained with H\&E (X40), and microscopically examined (Robinson, 1977).

4- Statistical analysis of data was conducted using SAS statistical package (1990).

\section{RESULTS}

1-Hematological parameters: RBCs count showed a significant $\downarrow$ in the $2^{\text {nd }}$ all over the whole period of the experiment. In group 3 and 4 the $\downarrow$ was recorded in 
the $10^{\text {th }}$ and $12^{\text {th }}$ weeks. No significant change in RBCs count was observed at the 2, 4, 6 and $8^{\text {th }}$ weeks of exposure in comparison with control group (tab. 1). The only significant difference between group 3 and group 4 was at the $4^{\text {th }}$ week in which RBCs count was within the normal value. Mean corpuscular volume (MCV) showed significant $\downarrow$ starting from the $6^{\text {th }}$ week till the end of the experiment in groups 2, 3 and 4 (tab. 2). Haematocrit percent was significantly $\downarrow$ in groups 2, 4 all over the whole period of the experiment and in the $6^{\text {th }}, 8^{\text {th }}, 10^{\text {th }}$ and $12^{\text {th }}$ weeks in case of group 3 . At $2^{\text {nd }} \& 4^{\text {th }}$ weeks group 3 showed a significant $\uparrow$ when compared with $4^{\text {th }}$ group. The result of the $3^{\text {rd }}$ group was within the limit of $1^{\text {st }}$ group at $6^{\text {th }}, 8^{\text {th }}, 10^{\text {th }}$ and $12^{\text {th }}$ weeks (tab. 3). A significant $\downarrow$ of hemoglobin was recorded during the whole period of the experiment in $2^{\text {nd }}$ group and in $8^{\text {th }}, 10^{\text {th }}$ and $12^{\text {th }}$ weeks in $4^{\text {th }}$ group and only at the week $12^{\text {th }}$ in $3^{\text {rd }}$ group (tab. 4). A significant $\downarrow$ in $\mathrm{MCH}$ values was recorded in groups 2,3 and 4 at studied periods except at $2^{\text {nd }}$ week where no significant change in groups 3, 4 (tab. 5).

WBCs count showed significant $\uparrow$ in $2^{\text {nd }}, 4^{\text {th }}$ weeks in groups 2 and 3 and significant $\downarrow$ at $10^{\text {th }} \& 12^{\text {th }}$ weeks. In the $4^{\text {th }}$ group, a significant $\downarrow$ was noticed at $6^{\text {th }}, 8^{\text {th }}$, $10^{\text {th }}$ and $12^{\text {th }}$ weeks (tab. 6). Lymphocyte count showed significant $\downarrow$ in $2 \& 3$ groups at $10^{\text {th }} \& 12^{\text {th }}$ weeks but in group 4 it was recorded at the $12^{\text {th }}$ week (tab.7). The results of granulocyte count significantly $\downarrow$ at the first period ( $2^{\text {nd }}$ week) in all groups $(2,3$ and 4 ) and at $8^{\text {th }}, 10^{\text {th }}$ and $12^{\text {th }}$ weeks in group 2 (tab. 8). Monocyte count significantly $\downarrow$ in groups $2,3,4$ at $8^{\text {th }}, 10^{\text {th }}$ and $12^{\text {th }}$ weeks (tab. 9).

Table 1: Efficacy of DMSA and DMPS treatment on RBCs count (million/ $/ \mathrm{mm}^{3}$ ).

\begin{tabular}{|c|c|c|c|c|c|c|}
\hline \multirow{2}{*}{ Rats groups } & \multicolumn{4}{|c|}{ Post-exposure time (weeks) } & \multirow[b]{2}{*}{10} & \multirow[b]{2}{*}{12} \\
\hline & 2 & 4 & 6 & 8 & & \\
\hline 1 & $7.60 \pm 0.31$ & $6.58 \pm 0.37$ & $6.69 \pm 0.24$ & $6.80 \pm 0.30$ & $7.01 \pm 0.41$ & $6.8^{\vee} \pm 0.43$ \\
\hline 2 & $5.87 \pm 0.25^{*}$ & $5.73 \pm 0.51^{*}$ & $5.58 \pm 0.49^{*}$ & $5.02 \pm 0.28 *$ & $4.90 \pm 0.32 *$ & $5.13 \pm 0.32 *$ \\
\hline 3 & $6.89 \pm 0.29$ & $7.18 \pm 0.25^{\mathrm{a}}$ & $6.39 \pm 0.38$ & $6.09 \pm 0.33^{\mathrm{a}}$ & $5.65 \pm 0.34^{*}$ & $5.29 \pm 0.39 *$ \\
\hline 4 & $6.73 \pm 0.52$ & $5.83 \pm 0.18^{\mathbf{b}}$ & $5.72 \pm 0.40$ & $5.59 \pm 0.30$ & $5.42 \pm 0.43 *$ & $5.03 \pm 0.32 *$ \\
\hline
\end{tabular}

Table 2: Efficacy of DMSA and DMPS treatment on MCV.

\begin{tabular}{|c|c|c|c|c|c|c|}
\hline \multirow{2}{*}{$\begin{array}{c}\text { Rats } \\
\text { Groups }\end{array}$} & \multicolumn{4}{|c|}{ Post-exposure time (weeks) } & \multirow[b]{2}{*}{10} & \multirow[b]{2}{*}{12} \\
\hline & 2 & 4 & 6 & 8 & & \\
\hline 1 & $54.5 \pm 1.4$ & $56.7 \pm 1.1$ & $55.3 \pm 1.6$ & $56.3 \pm 1.3$ & $54.8 \pm 1.4$ & $56.8 \pm 2.3$ \\
\hline 2 & $53.8 \pm 1.2$ & $52.1 \pm 0.9$ & $48.2 \pm 0.9^{*}$ & $48.5 \pm 0.8^{*}$ & $45.3 \pm 1.6^{*}$ & $44.3 \pm 3.6^{*}$ \\
\hline 3 & $60.3 \pm 2.4^{\mathrm{a}}$ & $52.1 \pm 2.9$ & $49.2 \pm 1.5^{*}$ & $47.3 \pm 0.9^{*}$ & $50.2 \pm 1.1$ & $41.8 \pm 1.3 *$ \\
\hline 4 & $56.2 \pm 1.4$ & $54.7 \pm 0.8$ & $50.8 \pm 1.0 *$ & $47.2 \pm 0.8^{*}$ & $49.6 \pm 2.4^{*}$ & $43.5 \pm 1.5^{*}$ \\
\hline
\end{tabular}

$*$ : means significant at $\mathrm{p} \leq 0.05$ to 0.01 in comparison with the $1^{\text {st }}$ group.

a: means significant difference between the $2^{\text {nd }}$ group and both $3^{\text {rd }} \& 4^{\text {th }}$ groups. 
Table 3: Efficacy of DMSA and DMPS treatment on HCT (\%).

\begin{tabular}{ccccccc}
\hline \multirow{2}{*}{$\begin{array}{c}\text { Rats } \\
\text { Groups }\end{array}$} & 2 & 4 & 6 & 8 & 10 & 12 \\
\cline { 2 - 6 } & $44.4 \pm 1.6$ & $42.4 \pm 1.6$ & $43.7 \pm 1.8$ & $43.3 \pm 1.2$ & $43.6 \pm 1.9$ & $43.8 \pm 1.5$ \\
\hline 1 & $34.9 \pm 2.5^{*}$ & $36.0 \pm 0.7^{*}$ & $34.3 \pm 0.5^{*}$ & $31.7 \pm 0.9^{*}$ & $32.5 \pm 0.6^{*}$ & $34.0 \pm 0.7^{*}$ \\
\hline 2 & $41.1 \pm 0.9^{\mathbf{a}}$ & $41.9 \pm 1.99^{\mathbf{a}}$ & $36.3 \pm 0.9^{*}$ & $35.3 \pm 0.6^{* \mathrm{a}}$ & $35.4 \pm 1.7^{*}$ & $37.7 \pm 0.5^{* \mathrm{a}}$ \\
\hline 3 & $38.4 \pm 0.4^{* \mathrm{~b}}$ & $37.1 \pm 1.2^{* \mathbf{b}}$ & $35.3 \pm 2.4^{*}$ & $36.1 \pm 0.9^{* \mathrm{a}}$ & $33.0 \pm 0.6^{*}$ & $36.3 \pm 0.9^{*}$ \\
\hline 4 & &
\end{tabular}

*: means significant at $\mathrm{p} \leq 0.05$ to 0.01 in comparison with the $1^{\text {st }}$ group.

a: means significant difference between the $2^{\text {nd }}$ group and both $3^{\text {rd }} \& 4^{\text {th }}$ groups.

b: means significant difference between group 3 and 4 .

Table 4: Efficacy of DMSA and DMPS treatment on $\mathrm{Hb}(\mathrm{g} / \mathrm{dl})$.

\begin{tabular}{ccccccc}
\hline & \multicolumn{7}{c}{ Post-exposure time (weeks) } & & \\
\cline { 2 - 6 } Rats groups & 2 & 4 & 6 & 8 & 10 & 12 \\
\hline 1 & $14.1 \pm 0.2$ & $14.4 \pm 1.1$ & $12.6 \pm 1.2$ & $14.0 \pm 1.1$ & $14.5 \pm 0.3$ & $13.9 \pm 0.7$ \\
\hline 2 & $11.3 \pm 0.7^{*}$ & $11.9 \pm 0.4^{*}$ & $10.9 \pm 0.3^{*}$ & $10.9 \pm 0.5^{*}$ & $10.8 \pm 0.5^{*}$ & $10.8 \pm 0.2^{*}$ \\
\hline 3 & $12.8 \pm 0.3$ & $13.5 \pm 0.3$ & $13.5 \pm 0.2^{\mathbf{a}}$ & $12.8 \pm 0.2^{\mathbf{a}}$ & $13.9 \pm 0.3^{\mathbf{a}}$ & $11.5 \pm 0.1^{*}$ \\
\hline 4 & $12.5 \pm 0.8$ & $12.9 \pm 0.3$ & $12.0 \pm 0.5$ & $11.9 \pm 0.4^{*}$ & $11.2 \pm 0.5^{* \mathbf{b}}$ & $9.8 \pm 1.0^{*}$ \\
\hline
\end{tabular}

*: means significant at $\mathrm{p} \leq 0.05$ to 0.01 in comparison with the $1^{\text {st }}$ group.

a: means significant difference between the $2^{\text {nd }}$ group and both $3^{\text {rd }} \& 4^{\text {th }}$ groups.

b: means significant difference between group 3 and 4 .

Table 5: Efficacy of DMSA and DMPS treatment on MCH (pg).

\begin{tabular}{ccccccc}
\hline & \multicolumn{7}{c}{ Post-exposure time (weeks) } \\
\cline { 2 - 6 } Rats groups & 2 & 4 & 6 & 8 & 10 & 12 \\
\hline 1 & $20.1 \pm 0.3$ & $20.9 \pm 0.5$ & $20.5 \pm 0.2$ & $20.6 \pm 0.7$ & $21.2 \pm 0.5$ & $20.9 \pm 0.5$ \\
\hline 2 & $18.6 \pm 0.3^{*}$ & $18.3 \pm 0.3^{*}$ & $16.8 \pm 0.3^{*}$ & $16.7 \pm 0.4^{*}$ & $16.1 \pm 0.5^{*}$ & $15.9 \pm 0.4^{*}$ \\
\hline 3 & $20.5 \pm 0.2^{\mathbf{a}}$ & $17.9 \pm 0.5^{*}$ & $16.8 \pm 0.2^{*}$ & $17.2 \pm 0.4^{*}$ & $17.8 \pm 0.4^{* \mathrm{a}}$ & $17.3 \pm 0.4^{*^{\mathrm{a}}}$ \\
\hline 4 & $20.6 \pm 0.2^{\mathrm{a}}$ & $19.4 \pm 0.3^{* \mathrm{~b}}$ & $17.2 \pm 0.3^{*}$ & $17.3 \pm 0.3^{*}$ & $17.9 \pm 0.3^{* \mathrm{a}}$ & $17.7 \pm 0.3^{* \mathrm{a}}$ \\
\hline
\end{tabular}

*: means significant at $\mathrm{p} \leq 0.05$ to 0.01 in comparison with the $1^{\text {st }}$ group.

a: means significant difference between the $2^{\text {nd }}$ group and both $3^{\text {rd }} \& 4^{\text {th }}$ groups.

b: means significant difference between group 3 and 4 .

Table 6: Efficacy of DMSA and DMPS treatment on WBCs count $\left(10^{3} / \mathrm{mm}^{3}\right)$.

\begin{tabular}{ccccccc}
\hline & \multicolumn{5}{c}{ Post-exposure time (weeks) } \\
\cline { 2 - 6 } Rats groups & 2 & 4 & 6 & 8 & 10 & 12 \\
\hline 1 & $11.4 \pm 0.4$ & $12.1 \pm 0.6$ & $12.2 \pm 0.8$ & $12.2 \pm 0.5$ & $11.8 \pm 0.5$ & $12.6 \pm 0.6$ \\
\hline 2 & $14.8 \pm 1.18^{*}$ & $15.48 \pm 1.3^{*}$ & $12.6 \pm 0.6$ & $8.9 \pm 0.8^{*}$ & $6.6 \pm 0.7^{*}$ & $6.8 \pm 0.6^{*}$ \\
\hline 3 & $13.4 \pm 1.1^{*}$ & $16.3 \pm 1.2^{*}$ & $14.1 \pm 1.0$ & $13.3 \pm 1.3^{\mathrm{a}}$ & $7.1 \pm 0.6^{*}$ & $7.6 \pm 0.9^{*}$ \\
\hline 4 & $10.4 \pm 1.2^{\mathbf{a}}$ & $13.0 \pm 0.7^{\mathbf{b}}$ & $9.0 \pm 0.7^{* \mathbf{a b}}$ & $8.6 \pm 0.6^{* \mathbf{b}}$ & $8.6 \pm 0.5^{* \mathbf{a}}$ & $7.8^{*} 0.5^{*}$ \\
\hline
\end{tabular}

*: means significant at $\mathrm{p} \leq 0.05$ to 0.01 in comparison with the $1^{\text {st }}$ group.

a: means significant difference between the $2^{\text {nd }}$ group and both $3^{\text {rd }} \& 4^{\text {th }}$ groups.

b: means significant difference between group 3 and 4 . 
$\underline{\text { Assiut Vet. Med. J. Vol. } 60 \text { No. } 142 \text { July } 2014}$

Table 7: Efficacy of DMSA and DMPS treatment on Lymphocyte count $\left(10^{3} / \mathrm{mm}^{3}\right)$.

\begin{tabular}{ccccccc}
\hline & \multicolumn{5}{c}{ Post-exposure time (weeks) } \\
\cline { 2 - 7 } Rats groups & 2 & 4 & 6 & 8 & 10 & 12 \\
\hline 1 & $08.1 \pm 0.7$ & $8.3 \pm 0.9$ & $8.1 \pm 0.4$ & $7.3 \pm 0.7$ & $8.2 \pm 0.9$ & $8.2 \pm 0.9$ \\
\hline 2 & $11.4 \pm 0.8^{*}$ & $10.2 \pm 1.1$ & $8.4 \pm 0.4$ & $5.8 \pm 0.4$ & $5.9 \pm 0.8^{*}$ & $5.5 \pm 0.3^{*}$ \\
\hline 3 & $09.0 \pm 0.5$ & $8.40 \pm 0.8$ & $8.5 \pm 0.8$ & $6.50 \pm 0.7$ & $5.0 \pm 0.60^{*}$ & $5.6 \pm 0.31^{*}$ \\
\hline 4 & $09.2 \pm 1.4$ & $10.3 \pm 0.8$ & $8.0 \pm 0.8$ & $6.9 \pm 0.7$ & $6.9 \pm 0.3$ & $5.2 \pm 1.18^{*}$ \\
\hline
\end{tabular}

*: means significant at $\mathrm{p} \leq 0.05$ to 0.01 in comparison with the $1^{\text {st }}$ group.

Table 8: Efficacy of DMSA and DMPS treatment on Granulocyte count $\left(10^{3} / \mathrm{mm}^{3}\right)$.

\begin{tabular}{ccccccc}
\hline Rats groups & \multicolumn{6}{c}{ Post-exposure time (weeks) } \\
\cline { 2 - 7 } & 2 & 4 & 6 & 8 & 10 & 12 \\
\hline 1 & $3.6 \pm 0.6$ & $2.7 \pm 0.4$ & $2.7 \pm 0.3$ & $3.0 \pm 0.3$ & $3.2 \pm 0.4$ & $3.0 \pm 0.4$ \\
\hline 2 & $2.3 \pm 0.33^{*}$ & $1.9 \pm 0.3$ & $1.8 \pm 0.3$ & $1.9 \pm 0.2^{*}$ & $1.7 \pm 0.2^{*}$ & $1.7 \pm 0.3^{*}$ \\
\hline 3 & $2.2 \pm 0.4^{*}$ & $2.3 \pm 0.2$ & $2.1 \pm 0.6$ & $3.5 \pm 0.3^{\mathrm{a}}$ & $1.9 \pm 0.3^{*}$ & $2.8 \pm 0.4^{\mathrm{a}}$ \\
\hline 4 & $1.8 \pm 0.3^{*}$ & $1.9 \pm 0.3$ & $1.6 \pm 0.2^{*}$ & $2.0 \pm 0.3^{* \mathrm{~b}}$ & $2.8 \pm 0.2^{\mathrm{a}}$ & $2.2 \pm 0.2$ \\
\hline
\end{tabular}

*: means significant at $\mathrm{p} \leq 0.05$ to 0.01 in comparison with the $1^{\text {st }}$ group.

a: means significant difference between the $2^{\text {nd }}$ group and both $3^{\text {rd }} \& 4^{\text {th }}$ groups.

b: means significant difference between group 3 and 4 .

Table 9: Efficacy of DMSA and DMPS treatment on Monocyte count $\left(10^{3} / \mathrm{mm}^{3}\right)$.

\begin{tabular}{ccccccc}
\hline \multirow{2}{*}{ Rats groups } & \multicolumn{7}{c}{ Post-exposure time (weeks) } \\
\cline { 2 - 7 } & 2 & 4 & 6 & 8 & 10 & 12 \\
\hline 1 & $1.080 \pm$ & $1.160 \pm$ & $1.080 \pm$ & $1.160 \pm$ & $1.200 \pm$ & $3.060 \pm$ \\
& 0.097 & 0.157 & 0.166 & 0.199 & 0.210 & 1.664 \\
\hline 2 & $1.100 \pm$ & $1.080 \pm$ & $0.700 \pm$ & $0.640 \pm$ & $0.560 \pm$ & $0.540 \pm$ \\
& 0.130 & 0.136 & 0.045 & $0.040^{*}$ & $0.051^{*}$ & $0.024^{*}$ \\
\hline 3 & $1.300 \pm$ & $1.200 \pm$ & $1.120 \pm$ & $0.600 \pm$ & $0.720 \pm$ & $1.000 \pm$ \\
& 0.202 & 0.063 & 0.235 & $0.122^{* a}$ & $0.086^{*}$ & 0.032 \\
\hline 4 & $0.880 \pm$ & $1.040 \pm$ & $0.660 \pm$ & $0.600 \pm$ & $0.640 \pm$ & $0.860 \pm$ \\
& $0.058 \mathrm{~b}$ & $0.172^{\mathrm{b}}$ & $0.040^{\mathrm{b}}$ & $0.089^{*}$ & $0.075^{*}$ & 0.129 \\
\hline
\end{tabular}

$*$ : means significant at $\mathrm{p} \leq 0.05$ to 0.01 in comparison with the $1^{\text {st }}$ group.

a: means significant difference between the $2^{\text {nd }}$ group and both $3^{\text {rd }} \& 4^{\text {th }}$ groups.

b: means significant difference between group 3 and 4 .

2-Enzymes activities: The results of enzymes activities was significantly decreased in serum AST at the $12^{\text {th }}$ week in the $2^{\text {nd }}$ group and significant increase at the $2^{\text {nd }}$ week in both groups 3,4 in relation to the 2 group (tab. 10). The same result was obtained in serum ALT as significant decrease in group 2 at $10^{\text {th }} \& 12^{\text {th }}$ weeks and significant increase in groups 3,4 at the $2^{\text {nd }} \& 4^{\text {th }}$ weeks in relation to the group 2 (tab. 11). Gamma-GT values showed no significant change in group 2 in comparison with the control group. On the other hand a significant decrease in group 3, 4 was recorded at the $2^{\text {nd }}, 4^{\text {th }}$, and $6^{\text {th }}$ weeks in comparison with both groups 1,2 (tab. 12). 
Table 10: Efficacy of DMSA and DMPS treatment on AST in serum (IU/1).

\begin{tabular}{ccccccc}
\hline \multirow{2}{*}{ Rats groups } & \multicolumn{7}{c}{ Post-exposure time (weeks) } \\
\cline { 2 - 7 } & 2 & 4 & 6 & 8 & 10 & 12 \\
\hline 1 & $24.79 \pm$ & $31.92 \pm$ & $30.91 \pm$ & $28.71 \pm$ & $28.35 \pm$ & $33.57 \pm$ \\
2 & 2.670 & 1.549 & 4.244 & 3.263 & 3.656 & 2.775 \\
\hline 3 & $29.04 \pm$ & $29.25 \pm$ & $32.58 \pm$ & $28.24 \pm$ & $24.67 \pm$ & $19.74 \pm$ \\
3 & 2.679 & 3.124 & 1.612 & 5.431 & 4.002 & $4.222^{*}$ \\
\hline & $38.71 \pm$ & $30.21 \pm$ & $28.92 \pm$ & $29.10 \pm$ & $33.93 \pm$ & $31.26 \pm$ \\
4 & $0.445^{* a}$ & $3.040^{\mathrm{a}}$ & 5.324 & 1.604 & 0.586 & $1.591^{\mathrm{a}}$ \\
\hline
\end{tabular}

$*$ : means significant at $\mathrm{p} \leq 0.05$ to 0.01 in comparison with the $1^{\text {st }}$ group.

a: means significant difference between the $2^{\text {nd }}$ group and both $3^{\text {rd }} \& 4^{\text {th }}$ groups.

b: means significant difference between group 3 and 4 .

Table 11: Efficacy of DMSA and DMPS treatment on ALT in serum (IU/1).

\begin{tabular}{ccccccc}
\hline & \multicolumn{5}{c}{ Post-exposure time (weeks) } \\
\cline { 2 - 7 } Rats groups & 2 & 4 & 6 & 8 & 10 & 12 \\
\hline \multirow{2}{*}{1} & $36.80 \pm$ & $30.06 \pm$ & $30.72 \pm$ & $32.90 \pm$ & $29.47 \pm$ & $34.62 \pm$ \\
2 & 3.918 & 3.226 & 1.916 & 3.246 & 1.891 & 0.937 \\
\hline \multirow{2}{*}{3} & $26.09 \pm$ & $22.99 \pm$ & $29.10 \pm$ & $26.24 \pm$ & $23.62 \pm$ & $21.36 \pm$ \\
& 3.523 & 3.967 & 2.306 & 0.733 & $1.104^{*}$ & $1.797^{*}$ \\
\hline & $32.59 \pm$ & $29.01 \pm$ & $30.26 \pm$ & $31.19 \pm$ & $27.36 \pm$ & $29.94 \pm$ \\
& $1.332^{* \mathrm{a}}$ & $3.115^{\mathrm{a}}$ & 2.198 & 4.388 & 2.295 & $3.184^{\mathrm{a}}$ \\
\hline
\end{tabular}

$*$ : means significant at $\mathrm{p} \leq 0.05$ to 0.01 in comparison with the $1^{\text {st }}$ group.

a: means significant difference between the $2^{\text {nd }}$ group and both $3^{\text {rd }} \& 4^{\text {th }}$ groups.

b: means significant difference between group 3 and 4 .

Table 12: Efficacy of DMSA and DMPS treatment on $\gamma$-GT in serum(IU/l).

\begin{tabular}{ccccccc}
\hline \multirow{2}{*}{$\begin{array}{c}\text { Rats } \\
\text { groups }\end{array}$} & \multicolumn{7}{c}{ Post-exposure time (weeks) } \\
\cline { 2 - 7 } & 2 & 4 & 6 & 8 & 10 & 12 \\
\hline & $0.837 \pm$ & $0.851 \pm$ & & $0.788 \pm$ & $0.647 \pm$ & $0.827 \pm$ \\
& 0.061 & 0.131 & $0.873 \pm 0.043$ & 0.096 & 0.116 & 0.140 \\
\hline & $1.263 \pm$ & $0.840 \pm$ & $0.763 \pm$ & $0.877 \pm$ & $0.867 \pm$ \\
3 & $0.281^{*}$ & 0.158 & $0.977 \pm 0.130$ & 0.035 & 0.162 & 0.034 \\
\hline & $0.610 \pm$ & $0.527 \pm$ & $0.617 \pm$ & $0.567 \pm$ & $0.710 \pm$ & $0.760 \pm$ \\
4 & $0.082^{* \mathrm{a}}$ & $0.073^{* \mathrm{a}}$ & $0.063^{* \mathrm{a}}$ & 0.096 & 0.015 & 0.012 \\
\hline & $0.557 \pm$ & $0.580 \pm$ & $0.463 \pm$ & $0.460 \pm$ & $0.873 \pm$ & $0.853 \pm$ \\
& $0.024^{* \mathrm{a}}$ & $0.074^{* \mathrm{a}}$ & $0.034^{* \mathrm{a}}$ & $0.021^{* \mathrm{a}}$ & 0.061 & 0.018 \\
\hline
\end{tabular}

$*$ : means significant at $\mathrm{p} \leq 0.05$ to 0.01 in comparison with the $1^{\text {st }}$ group.

a: means significant difference between the $2^{\text {nd }}$ group and both $3^{\text {rd }} \& 4^{\text {th }}$ groups.

4-Clinical signs and histopathological changes:

Observation of investigated rats in groups 2, 3 and 4 revealed no apparent clinical signs. Macromorphological lesions recorded in all groups were only congestion of examined organs at different degree of severity. The microscopical examination of tissues was summarized in figures (1-18). 
1

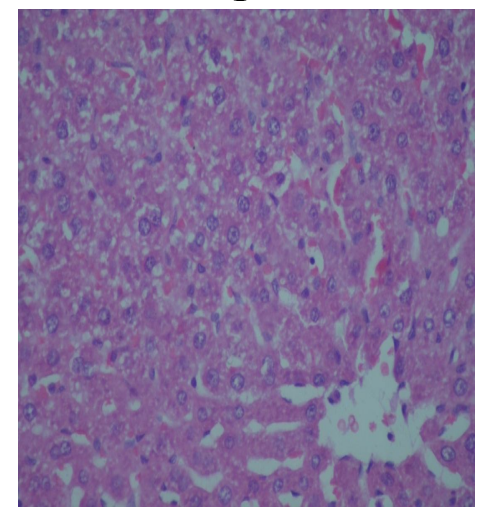

2

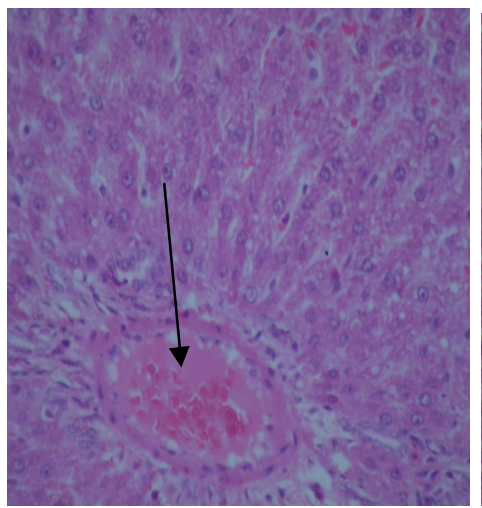

3

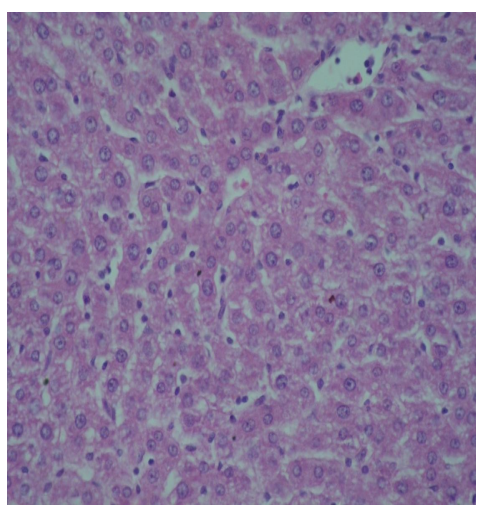

1: Liver (group 2) showing congestion and hydropic degeneration of the hepatocytes at $2^{\text {nd }}$ week.

2: Liver (group 2) showing thrombus formation in the central vein at $8^{\text {th }}$ week.

3: Liver (group 3) showing mild hydropic degeneration of the hepatocytes at $6^{\text {th }}$ week.

4

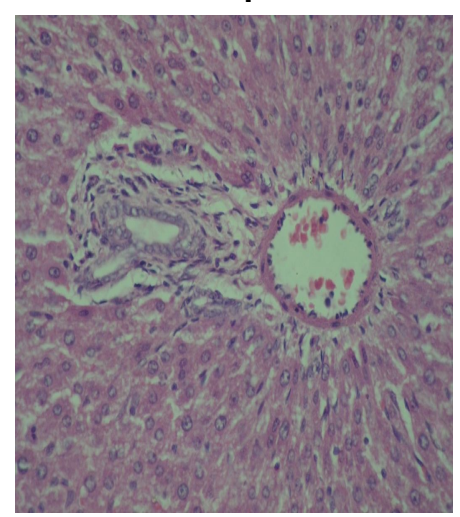

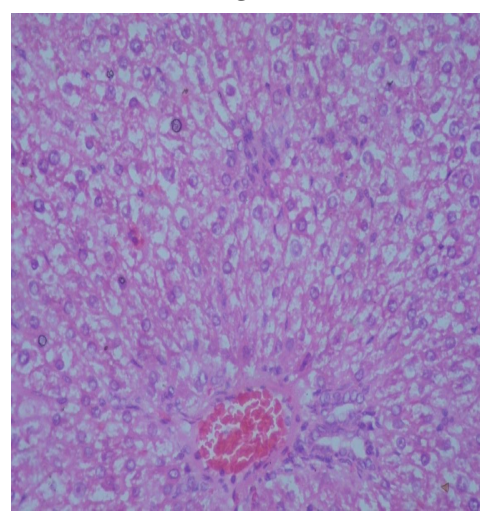

6

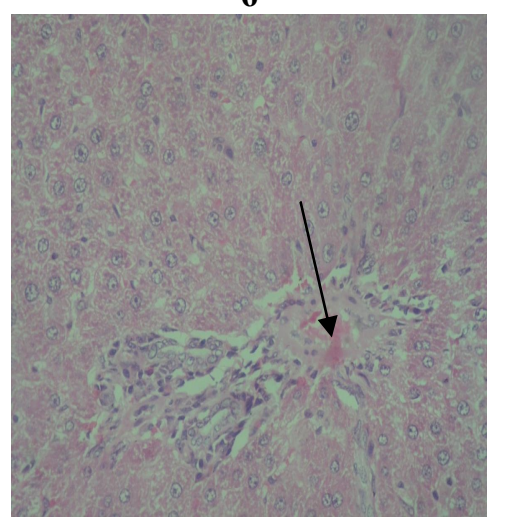

4: Liver (group 3): Fibrosis of portal area \& mild hydropic degeneration of the hepatocytes at $8^{\text {th }}$ week. 5: Liver (group 4): Moderate hydropic degeneration of hepatocytes $\&$ necrosis of vessel wall at $4^{\text {th }}$ week. 6: Liver (group 4) showing hydropic degeneration of the hepatocytes, hyperplasia of the bile duct, mononuclear cellular reaction \& thrombosis of the blood vessel at the $10^{\text {th }}$ week.

7

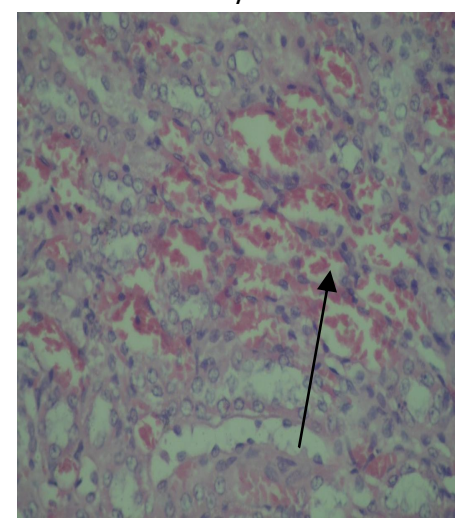

8

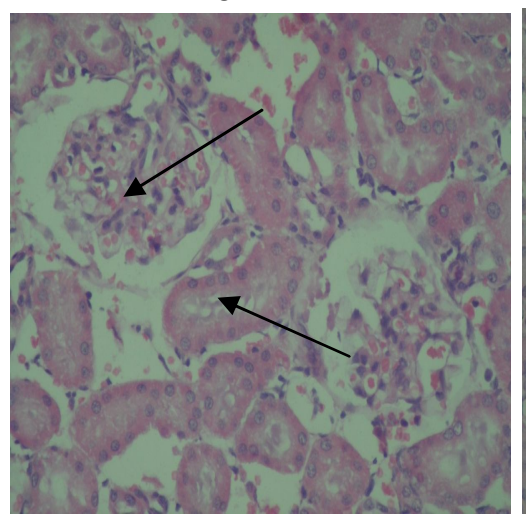

9

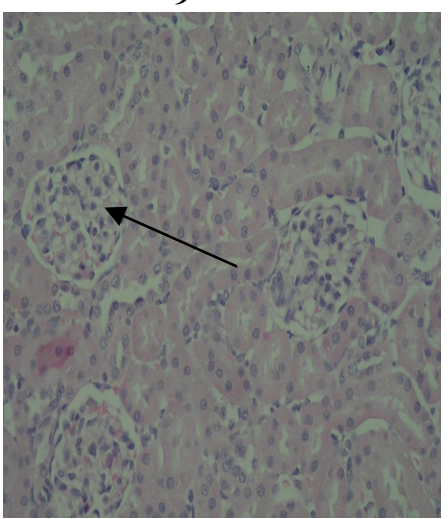

7: Renal medulla (group 2): Necrosis of the renal tubules with hemorrhage (arrow) at $6^{\text {th }}$ week.

8: Kidney (group 2): Necrosis of glomerular tufts \& Hydropic degeneration of renal tubules at $8^{\text {th }}$ week.

9: Renal cortex (group 3): Swelling of the glomerular tufts at the $2^{\text {nd }}$ week. H\&E. X40. 
10

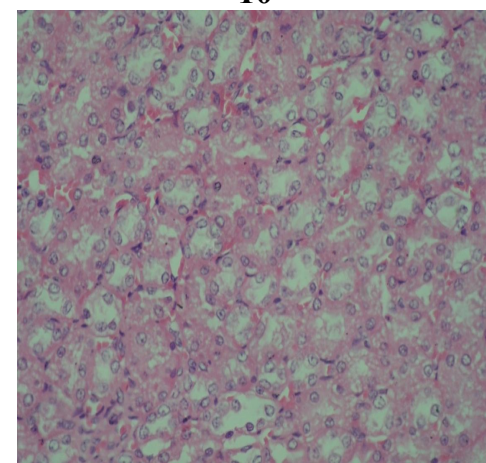

11

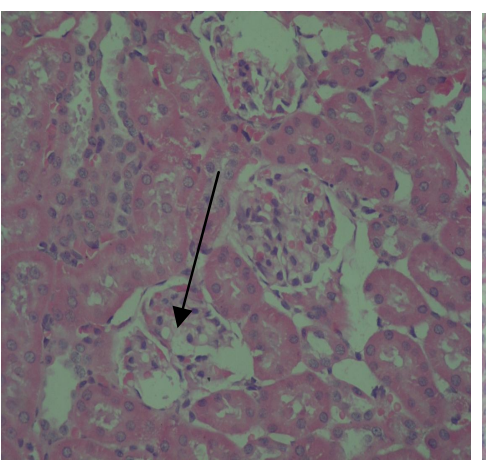

12

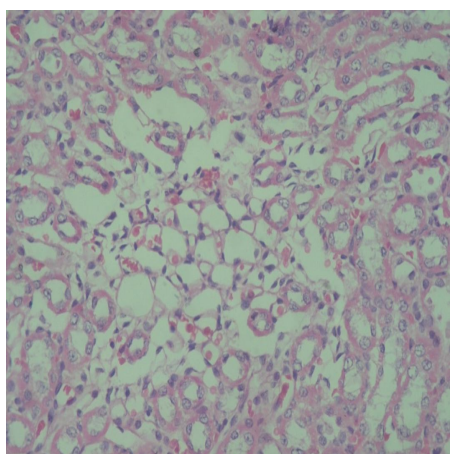

10: Renal medulla (group 3) showing mild hydropic degeneration of renal tubular epithelium at $6^{\text {th }}$ week.

11: Kidney (group 4) showing necrosis of the glomerular tufts at the $8^{\text {th }}$ week.

12: Kidney (group 4) showing cystic dilatation of the renal tubules at the $6^{\text {th }}$ week.

13

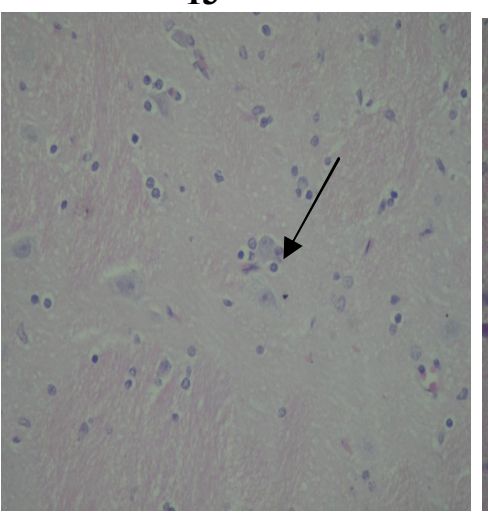

14

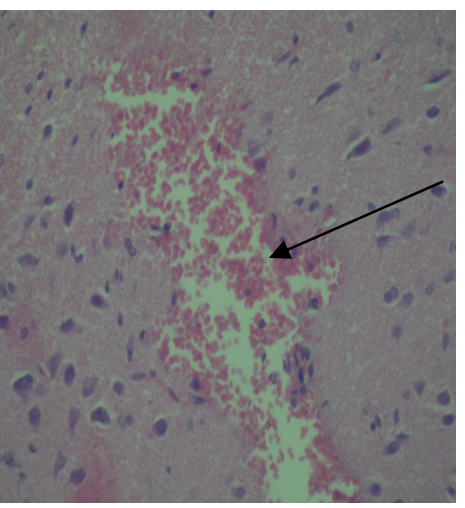

15

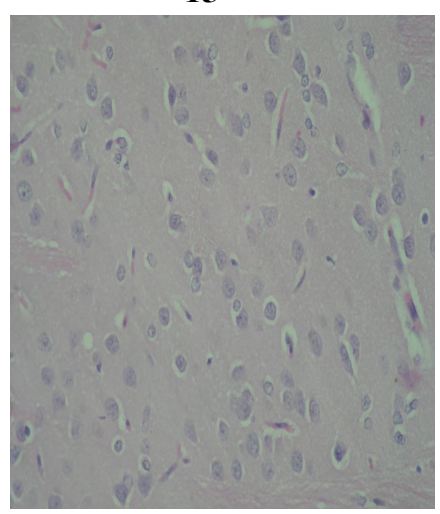

13: Brain (group 2) showing neurophagia at the $8^{\text {th }}$ week.

14: Brain (group 2) showing focal hemorrhage in the gray matter at the $12^{\text {th }}$ week.

15: Brain (group 3 ) showing perivascular $\&$ perineural edema at the $2^{\text {nd }}$ edema.

16

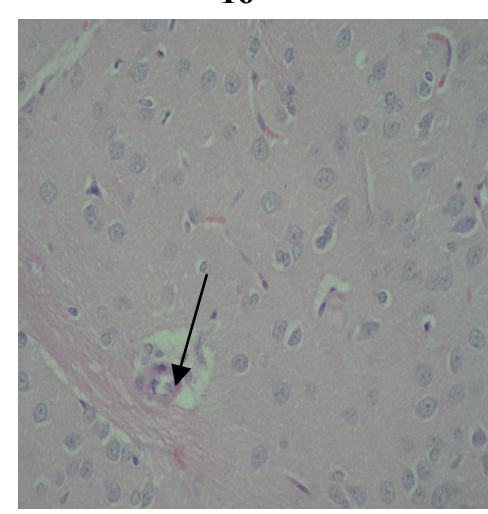

17

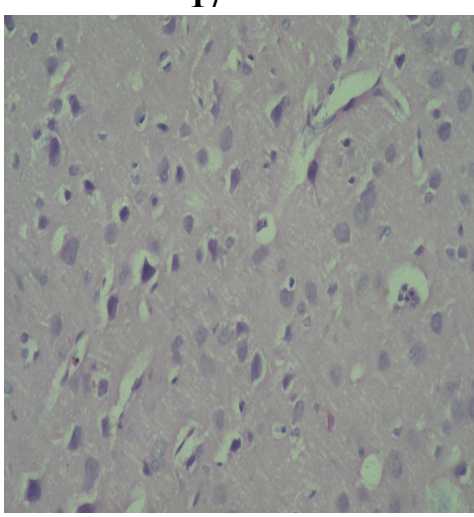

18

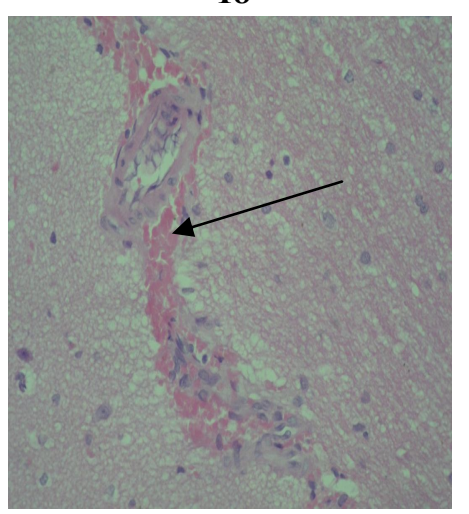

16: Brain (group 3): Perivascular \& perineural edema, perivascular cuff $\&$ degeneration of neurons at $12^{\text {th }}$ week.

17: Brain (group 4): Chromatolysis, degeneration of neurons, perineural \& perivascular edema at $2^{\text {nd }}$ week.

18: Brain (group 4): Degeneration of the wall of blood vessel and hemorrhage at the $8^{\text {th }}$ week. 


\section{DISCUSSION}

Lead has been the most causes of inorganic chemical poisoning in farm animals. For controlling such hazardous effects, the essential duty of toxicologist is the choice of an effective and non toxic treatment. The use of large number of chelating agents in treatment of lead toxicity initiated us to evaluate two of the most important chelators DMSA and DMPS.

The hematological picture in this study revealed that RBCs count was significantly decreased in group 2 all over the period of the experiment. In groups 3 and 4 the decrease was recorded in the $10^{\text {th }}$ and $12^{\text {th }}$ weeks. At the $2,4,6$ and $8^{\text {th }}$ weeks of exposure no significant decrease in RBCs count was observed in comparison to the control group. The only significant difference between group 3 and group 4 was at the $4^{\text {th }}$ week. The mean corpuscular volume (MCV) showed a significant decrease starting from the $6^{\text {th }}$ week till the $12^{\text {th }}$ week in all the 2, 3 and 4 groups. Hematocrit percent (\%) showed significant decrease in $2 \& 4$ groups all over the period of the experiment and in the $6^{\text {th }}$ week till the end of the experiment in group 3. At $2 \& 4$ weeks a significant increase when compared with group 4. The result of group 3 was within the limit of group 1 (control) at $6^{\text {th }}, 8^{\text {th }}, 10^{\text {th }}$ and $12^{\text {th }}$ weeks. Hemoglobin concentration showed significant decrease during the whole period of the experiment in group 2 and from the $8^{\text {th }}$ to the $12^{\text {th }}$ week in group 4 and at the last week $\left(12^{\text {th }}\right)$ only in group 3. A significant decrease in $\mathrm{MCH}$ values was recorded in 2, 3 and 4 groups at all periods except the $2^{\text {nd }}$ week which showed no significant decrease in both $3 \& 4$ group. Similarly, significant decrease in $\mathrm{Hb}, \mathrm{PCV}$, $\mathrm{MCH}, \mathrm{MCV}$ and $\mathrm{MCHC}$ were observed following exposure of rats to lead acetate (Helmy et al., 2000). Reduction in RBCs, PCV, $\mathrm{Hb}, \mathrm{MCV}, \mathrm{MCH}$ and $\mathrm{MCHC}$ was also observed by Klassen (2001) following exposure of lead acetate in rats that showed microcytic hypochromic anemia. This hematological alteration might be due to the effect of lead on activity of delta-aminolevulinic acid dehydratase (ALAD), key enzyme of heme synthesis. Moreover lead also inhibit the conversion of coproporphyrinogen III to protoporphyrin IX leading to reduction in hemoglobin production and shortened life span of erythrocytes. Lead suppresses bone marrow hematopoiesis, probably through its interaction with the enteric iron absorption (Chmielnika et al., 1994).

Our obtained results in this study was supported by Potula and $\mathrm{Hu}$ (1998) who mentioned that lead is a well known to inhibit the biosynthesis of heme and consequently of hemoglobin and to decrease the life span of circulationg red blood cells. Lead causes anemia when it combines with red blood cells and bone marrow. It damages the small blood vessels, causing bleeding، and deprives the nerves, the brain and other organs of oxygen. Lead severely damages the kidney and liver. It also causes sterility, fetal death and abortion. All animals with access to a source of lead are at risk. When one or two animals in a herd die or show signs of poisoning, other animals in the herd may also be suffering from lead poisoning. These animals may appear healthy, but be growing poorly as a result of subclinical lead poisoning (Siddiqui and Gayatri, 2008).

Anemia is a serious haematological manifestation of lead toxicity. Lead can induce two types of anemias, often accompanied by basophilic stippling of the erythrocytes (Holmes et al., 2008). Acute high-level lead exposure has been associated with hemolytic anemia. Frank anemia is manifested only when the blood lead level is significantly elevated for prolonged periods. In chronic lead exposure, $\mathrm{Pb}$ induces anemia by both interfering with heme biosynthesis and by diminishing red blood cell survival. Hemogolbin levels begin to decline at lead levels of 40-60 $\mu \mathrm{g} / \mathrm{dl}$ and prevalence of anemia increases with increase in blood lead level. However, the correlation between blood lead levels and hemoglobin levels are low (EPA, 2009). Investigation of triethyl lead on some hematological indices has revealed a significant decrease in the MCH, MCV and RBCs count. Lead inhibits the body's ability to make hemoglobin by interfering with several enzymatic steps in the heme pathway. Specifically, lead decreases heme biosynthesis by inhibiting ALA-D and ferrochelatase activity (EPA, 2009).

The anemia in lead-exposed individuals is of the hypochromic and normocytic (also) microcytic type and is accompanied by reticulocytosis with basophilic stippling. The shortened life span of erythrocytes is due to increased fragility of the 
blood cell membrane and reduced hemoglobin production is due to decreased levels of enzymes involved in heme synthesis (Guidotti et al., 2008).

High doses of lead in female rabbits induced mild anemia, reduced $\mathrm{MCH}, \mathrm{MCV}$ and $\mathrm{MCHC}$, low ALA-D and developed stippled RBCs (Falke and Zwennis, 1990). The hematological parameters were observed in adult rats following chronic lead intoxication in a 12 week period by Mughai et al. (2003). They found that $\mathrm{MCH}$ and MCV were decreased by $5.6 \%$ and $4.4 \%$, leukocytic count increased significantly by $11 \%$. Study of the different kinds of leukocytes revealed a $5.3 \%$ increase of lymphocyte count, neutrophils and monocytes increased by $21.2 \%$ and $70.2 \%$ respectively. A decrease of $69 \%$ was observed in the eosinophil count in the test group, which suggests eosinophilia following lead intoxication in rats. The previously recoded results were recoded in our study on rats.

WBCs count showed significant increase in the $2^{\text {nd }}$ and $4^{\text {th }}$ weeks in group 2 and 3 but it was significantly decreased at $10^{\text {th }} \& 12^{\text {th }}$ weeks. In group 4, The significant decrease was noticed from the $6^{\text {th }}$ week till the end of the experiment. Lymphocyte, granulocyte and monocytes showed the same change as WBCs count where they significantly decreased at the end of exposure, although this change appeared at the first period ( $2^{\text {nd }}$ week) in case of granulocytes. Decrease in total leucoctic count is directly related with either their decreased production from the germinal center of lymphoid organs or increased lysis due to presence of lead in the body (Avdheshkumar et al., 1998). Leukocyte counts in rats, which were administrated lead acetate, increased significantly by $11 \%$, compared to the control groups $(\mathrm{p}<0.05)$, which indicate leukocytosis (Mugahi et al., 2003). This might be due to direct toxic action of lead on leucopoiesis in lymphoid organs.

AST activity was significantly decreased at the $12^{\text {th }}$ week in group 2 although it was significantly increased at the $2^{\text {nd }}$ week in both 3 $\& 4$ groups in relation to the group 2 . The same behaviour was noticed in ALT activity. The gamma-GT values showed no significant change in group 2 in comparison with the control group. On the other hand, significant decrease in group $3 \& 4$ was recorded at the $2^{\text {nd }}, 4^{\text {th }}$, and $6^{\text {th }}$ weeks in comparison with both groups 1,2 . AST and
ALT which activities resulted from the escape of the enzymes to the serum from the injured liver cells. These two enzymes are members of transaminases groups of enzymes, which have a catalytic function. The determination of serum amino transaminases was considered as well as established methods for diagnosis of tissue necrosis and alteration of cellular permeability (Hochleithner, 1991). The obtained results of AST and ALT increased levels at the $2^{\text {nd }}$ week may be explained by Lumiej (1987) who mentioned that plasma transaminases activities remained elevated through a period of one week in case of non progressive necrosis.

The mild high levels in transferases in groups 3 , 4 may be explained by Haddad et al. (1998) who stated that hematologic alterations are more commonly encountered in subchronic or chronic toxicity, serum chemistry alterations particularly elevation in serum kidney parameters, may be seen in acute cases or during chelation therapy.

Suradkar et al. (2009) reported that increased AST and ALT might be due to increased cell membrane permeability or cell membrane damage of hepatocytes caused by lead acetate. These findings are in accordance with Shalan et al. (2005). Increase in GGT is an indication of hepatotoxicity and oxidative damage in the hepatocytes (Tatjana et al., 2003). Abdel Aal and Hussein (2008) who found in the treatment with DMSA or ALA, they improved the increased hepatic enzyme levels and this improvement was highly significant when ALA and DMSA were given in combination. This coincide with Shalan et al. (2005) who mentioned that administration of lead acetate in diet for 6 weeks resulted in elevations of serum GPT, GOT, and ALP, as recorded in this study in the $2^{\text {nd }}$ week in groups $3 \& 4$.

The effect of lead toxicity on liver functions which includes AST, ALT and alkaline phosphatase in treatment periods of 1-3 months were estimated by Moussa and Bashandy (2008). They recorded a significant increase in ALT and AST. These changes were time dependent. These results were similar to that recorded in our study.

DMSA is suggested as a chelation therapy for dogs in lead or zinc toxicosis because it's less toxic than calcium disodium EDTA and can be given orally. The given dose is $10 \mathrm{mg} / \mathrm{kg}$ bw orally/every 8 hours for 10 days (Peterson and Talcott, 2001). 
The absence of apparent clinical signs on exposed rats in groups 2, 3 and 4 is in agreement with Kirk (1986), who stated that chronic lead poisoning in dogs and cats is sometimes overlooked, because the signs can be insidious in onset and subtle in nature mimicking a variety of other ailments. The recorded lesions in liver, kidney and brain are inconsistence with that mentioned by Beasley (1999) as in chronic toxicosis it is possible to see fibrosis. Do not rule out lead toxicosis because of the absence of renal lesions. Degeneration and necrosis are sometimes prominent, acid-fast intranuclear inclusions may occur in the renal tubular epithelial cells. It can cause a degree of renal failure, although this is not usually a primary finding. Edema, swelling, increased prominence of vessels in the brain, capillary damage in the CNS and collapses of small arterioles had been recorded.

\section{CONCLUSION}

Concerning the aim of the present study and reviewing the obtained results we can conclude that: (1) DMSA is more effective than DMPS concerning the results of Red blood cells count, hemoglobin and monocytes. (2) DMPS is more effective than DMSA concerning the results of White blood cells count. (3) Both significantly increased the levels of AST \& ALT than lead group at $2^{\text {nd }}$ and $4^{\text {th }}$ weeks of exposure. (4) Both significantly decreased Gamma-gutamyl transferase $(\gamma-\mathrm{GT})$ in comparison with Lead group at $2^{\text {nd }}, 4^{\text {th }}$ and $6^{\text {th }}$ weeks. (5) The results of histopathological changes revealed a clear variance between group 3 and $2 \& 4$ groups. Most of the recorded lesions in liver, kidney and brain of groups $2 \& 4$ at severe or moderate degree were absent or in a mild form in $3^{\text {rd }}$ group.

\section{REFERENCES}

Abadin, H. and Llados, F. (1999): Toxicological profile for lead, Washington, D.C., Department of health and human services, pp. 19-257.

Abdel Aal, K.M. and Hussien, A.M.R. (2008): Therapeutic efficacy of alpha lipoic acid in combination with succimer against leadinduced oxidative stress, hepatotoxicity and nephrotoxicity in rats. Ass. Univ. Bull. Environ. Res., Vol. 11, No. 2: 87-98.
Anjana, G.Vij. (2009): Hemopoietic, hemostatic and mutagenic effects of lead and possible prevention by zinc and vitamin C. Al Ameen. J. Med. Sci. 2(2) special: 27-36.

Aposhian, H.V. and Aposhian, M.M. (1990): Meso2,3-dimercaptosuccinic acid: chemical, pharmacological and toxicological properties of an orally effective metal chelating agent. Annu. Rev. Pharmacol. Toxicol., 30: 279-306.

Avadheshkumar; Chauhan, R.S. and Singh, N.P. (1998): Immunopathological effect of lead on cell mediated immunity in chicken. Ind. J. Vet. Pathol., 22(1): 22-25.

Beasley, V. (1999): Nephrotoxic Metals and Inorganics- In Veterinary Toxicology, International Veterinary Information Service (www.ivis.org), Ithaca, New York, USA.

Chen, Z.K. and Lu, Z.Q. (2004): Sodium dimercaptopropane sulfonate as antidote against metallic pesticides: Acta. Pharmacol. Sin., 25(4): 534-544.

Chmielnika, J.; Zareba, G. and Nasiadek, M. (1994): Combined effect of tin and lead on heme biosynthesis in rats. Ecotox. Environm. Safety 29: 165-173.

EPA (2009): U.S.Environment Protection Agency, Office of research and development, National Center for Environment Assessment. Available at: http://toxnet.nim.nih.gov.

Falke, H.E. and Zwennis, W.C.M. (1990): Toxicity of lead acetate to female rabbits after chronic subcutaneous administration: Biochemical and clinical effects. Arch. Toxicol., 64: 522-529.

Guidotti, T.L.; McNamara, J. and Moses, M.S. (2008): The interpretation of trace elements analysis in body fluids. Indian. J. Med. Res., 128: 524-532.

Haddad, L.M.; Shannon, M.W. and Winchester, J.D. (1998): Clinical Management of Poisoning and Drug Overdose, $3 r d$ edition. Philadelphia: WB Saunders Company.

Helmy, M.A.; Elnaga, N.I. and Hela, S.M. (2000): Effect of administration of milk and kareish cheese on hematological values and histopthological changes in liver and brains of rat treated with lead. Alexandria J. Agril. Res., 45(2): 103-115.

Henery, J. (1960): Interpretation of Clinical Laboratory tests. Am. J. Clin. Path. 34-38.

Hochleithner, M. (1991): Eirisatz moglichkeit des Reflorot on beimzier vogel. (Use of Ref. Lotron $\AA^{\circledR}$ in pet birds). Tagungsberich MSA va Kongre B, Wein, pp. 585-587.

Holmes, A.L.; Wise, S.S. and Wise Sr. JP. (2008): Carcinogenicity of hexavalent chromium. Indian J. Med. Res., 128: 353-372.

Jubb, K.V.F.; Kennedy, P.C. and Palmer, N. (1993): Pathology of Domestic Animals, 4th. ed. San Diego: Academic Press. 
Kirk, R.W. (1986): Current veterinary therapy IX, Philadelphia, WB Saunders.

Klassen, C.D. (2001): Casarett's and Doull's toxicology: The basic Science of poisons. $6^{\text {th }}$ ed. McGraw-Hill Medical publishing division. Pp. 812-841.

Lumiej, J.T. (1987): A contribution to clinical methods for birds, with special references to racing pigeon. Utrecht, Proc. Fschrift.

Moussa, S.A. and Bashandy, S.A. (2008): Biophysical and biochemical changes in the blood of rats exposed to lead toxicity. Romanian J. Biophys., Vol. 18, No. 2, P. 123-133.

Mugahi, M.N.; Heidari, Z.; Sagheb, H.M. and Barbarestani, M. (2003): Effects of chronic lead intoxication on blood indices of male adult rat. DARU. Vol. 11,(4): 147-151.

Nielsen, J.B. and Andersen, O. (1991): Effect of fourthiol containing chelators on disposition of an orally administered mercuric chloride. Hum. Exp. Toxicol., 10: 423-430.

O'Connor, M.E. and Rich, D. (1999): Children with moderately elevated lead levels: Is chelation with DMSA helpful? Clin. Pediatr. (Phila), 38: 325-331.

Osweiler, G.D. (1996): Toxicology, The National Veterinary Medical series for independent study. Williams and Wilkins. USA.

Potula, V.L. and Hu, H. (1996): Int. J. Occup. Environ. Health, 2, 1-4.

Peterson, M.E. and Talcott, P.A. (2001): Small animal toxicology, Copyright, W.B. Saunders, USA, P373.
Robinson, G. (1977): Principals of electron microscopy and tissue preparation. Cited in theory and practice of histopathological techniques. Longman group. Limited.

SAS institute. (1990): SAS User's Guide, Version 6.07. SAS Institute, Inc, Cary, North Carolina, USA.

Shalan, M.G.; Mostafa, M.S.; Hassouna, M.M.; ElNabi, E.E. and El-Refaie (2005): Amelioration of lead toxicity on rat liver with vitamin $\mathrm{C}$ and silymarin supplements. Toxicol., 206(1): 1-15.

Siddiqui, M.F. and Gayatri, R.R. (2008): Lead an emerging threat to livestock. Veterinary world, Vol. 1(7): 213-216.

Sullivan, J.B. and Kriger, G.R. (1992): Hazardous materials toxicology, clinical principles of environmental health, Baltimore, Williams \& Wilkins.

Suradkar, S.G.; Ghodasara, D.J.; Vihol, P.; Patel, J.; Jaiswal, V. and Prajapati, K.S. (2009): Haemato-Biochemical alterations induced by lead acetate toxicity in wistar rats. Veterinary world, Vol. 2(11): 429-431.

Tatjana, J.; Gordana, K.; Dusica, P. and Ivana, S. (2003): Effects of captopril on membrane associated enzymes in lead induced hepatotoxicity in rats. Acta. Fac. Med. Naiss., 20(3): 183-188.

Tietz, N.W. (1994): Textbook of Clinical Chemistry. 2 nd ed. W. B. Sounder Co.; Philadelphia, P. 851.
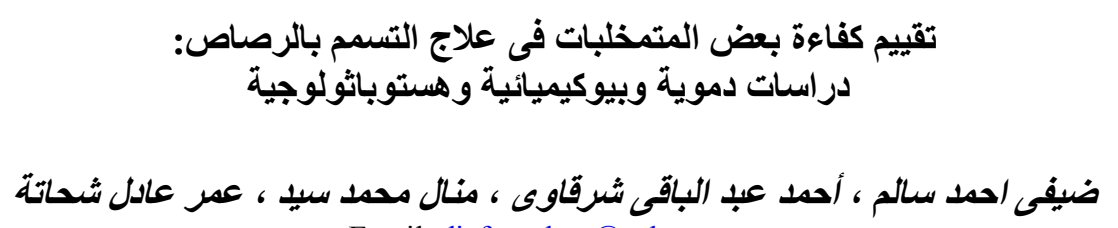

Email:diefy_salem@yahoo.com

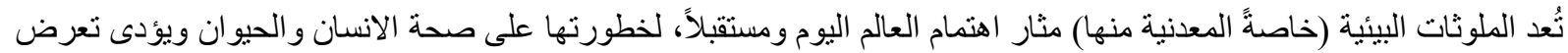

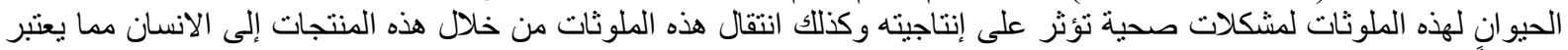

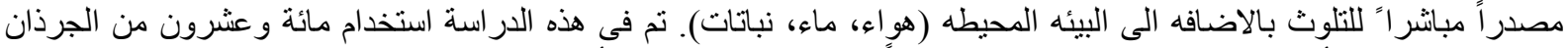

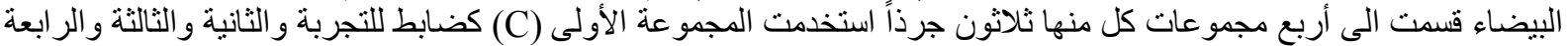

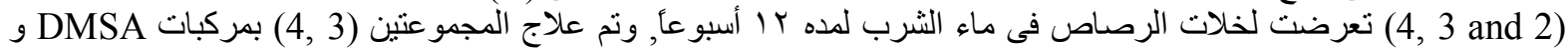

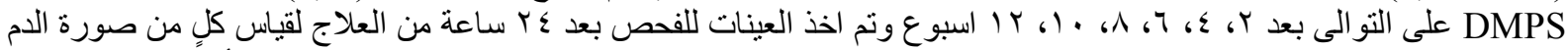

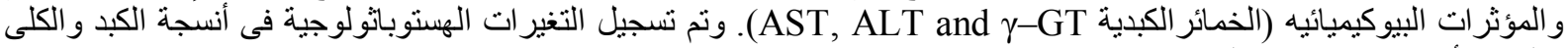

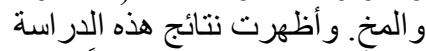

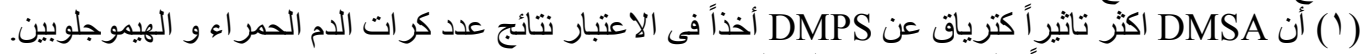

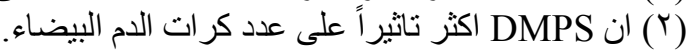

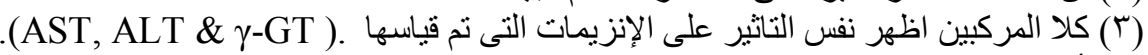

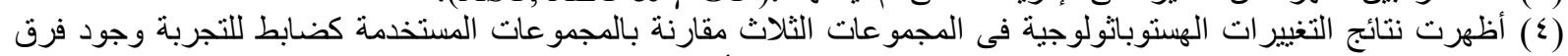

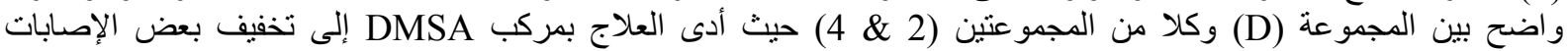

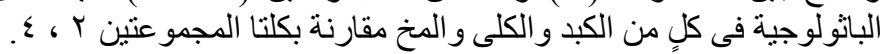

